\title{
Molecular Genetics and Functional Analysis Implicate CDKN2BAS1-CDKN2B Involvement in POAG Pathogenesis
}

\author{
Sonika Rathi ${ }^{1}$, Ian Danford ${ }^{1,2}$, Harini V. Gudiseva ${ }^{1}$, Lana Verkuil ${ }^{1}$, Maxwell Pistilli ${ }^{1}$ (D), \\ Sushma Vishwakarma ${ }^{3}$, Inderjeet Kaur ${ }^{3}{ }^{\circ}$, Tarjani Vivek Dave ${ }^{4}$, Joan M. O’Brien ${ }^{1, *,+}$ \\ and Venkata R. M. Chavali ${ }^{1, *,+}$ (D) \\ 1 Scheie Eye Institute, Department of Ophthalmology, Philadelphia, PA 19104, USA; \\ Sonika.Rathi@pennmedicine.upenn.edu (S.R.); ian.danford@gmail.com (I.D.); \\ gudiseva@pennmedicine.upenn.edu (H.V.G.); lanav@pennmedicine.upenn.edu (L.V.); \\ pistilli@pennmedicine.upenn.edu (M.P.) \\ 2 Casey Eye Institute, Oregon Health \& Science University, Portland, OR 97239, USA \\ 3 Prof Brien Holden Eye Research Centre, L. V. Prasad Eye Institute, Hyderabad, Telangana 500034, India; \\ svishwakarma17@gmail.com (S.V.); inderjeet@lvpei.org (I.K.) \\ 4 Ophthalmic Plastic Surgery Service, Prof Brien Holden Eye Research Centre, L. V. Prasad Eye Institute, \\ Hyderabad, Telangana 500034, India; tarjani@lvpei.org \\ * Correspondence: Joan.O’Brien@pennmedicine.upenn.edu (J.M.O.); \\ vchavali@pennmedicine.upenn.edu (V.R.M.C.) \\ + Authors contributed equally.
}

Received: 16 June 2020; Accepted: 17 August 2020; Published: 21 August 2020

\begin{abstract}
The genes in the 9p21 locus (CDKN2B-AS1 \& CDKN2B) are widely associated with Primary open-angle glaucoma (POAG). However, the functional importance of this locus in POAG pathogenesis is still unexplored. This study investigated the role of CDKN2BAS1-CDKN2B axis in POAG. We observed significant association of CDKN2B-AS1 SNP rs4977756 with POAG and its endophenotypic traits (vertical cup-disc ratio $(p=0.033)$ and central corneal thickness $(p=0.008)$ ) by screening African American POAG cases $(n=1567)$ and controls $(n=1600)$. A luciferase reporter assay in Human embryonic kidney 293T (HEK293T) cells revealed that the region surrounding rs4977756 likely serves as a transcriptional repressor. siRNA-mediated knockdown of CDKN2B-AS1 in HEK293T cells and trabecular meshwork (TM) cells resulted in significantly increased expression of $C D K N 2 B$, which was also observed in human POAG ocular tissues. Pathway focused qRT-PCR gene expression analysis showed increased cellular senescence, TGF $\beta$ signaling and ECM deposition in TM cells after $C D K N 2 B-A S 1$ suppression. In conclusion, we report that $C D K N 2 B-A S 1$ may act as a regulator, and it could function by modulating the expression of $C D K N 2 B$. In addition, increase in CDKN2B levels due to $C D K N 2 B-A S 1$ suppression may result in the senescence of trabecular meshwork cells leading to POAG pathogenesis.
\end{abstract}

Keywords: $C D K N 2 B-A S 1$; senescence; Primary open-angle glaucoma (POAG); trabecular meshwork cells; African Americans

\section{Introduction}

Primary open-angle glaucoma (POAG) is the most common form of glaucoma, characterized by optic nerve $(\mathrm{ON})$ degeneration and progressive loss of visual field leading to irreversible vision loss. POAG affects over 56 million people worldwide [1] and the number of patients diagnosed with POAG is expected to increase with increasing awareness and improvements to diagnostic technology [2]. 
Previous studies have revealed a higher prevalence of POAG in African Americans compared to European Americans and other populations globally [3] and in the United States [4,5].

POAG is a complex genetic disorder influenced by the interaction of multiple genes, risk factors and endophenotypic traits such as intraocular pressure (IOP), central corneal thickness (CCT), retinal fiber layer thickness (RNFL), and cup-to-disc ratio (CDR). Genome-wide association studies (GWAS) and candidate gene screening studies have identified the association of many genes including myocilin (MYOC), optineurin (OPTN), WD repeat domain 36 (WDR36), neurotrophic factor 4 (NTF4) and ankyrin repeat and SOCS box containing 10 (ASB10) with POAG and its endophenotypic traits [6-12]. Variants in these POAG associated genes may impair the proper functioning of retinal ganglion cells (RGCs) or trabecular meshwork cells (TMs) leading to optic nerve cupping and ocular hypertension [13].

Association studies across different populations have identified the 9p21 locus, consisting of $C D K N 2 B-A S 1, C D K N 2 B$, and $C D K N 2 A$ genes, as associated with POAG and its endophenotypic traits (VCDR and IOP) [14-17]. SNPs in this locus are also associated with atherosclerosis and cardiovascular diseases [18,19], type 2 diabetes [20], intracranial aneurysm [21], multiple forms of cancer [22] and inflammatory disease [23]. The CDKN2B-AS1 gene lies in the centromeric region of the 9p21 locus, and encodes a long noncoding RNA also known as ANRIL. This noncoding RNA plays a role in epigenetic regulation of gene expression through cis and trans-mechanisms [24]. The CDKN2A (cyclin dependent kinase inhibitor $2 \mathrm{~A}$ ) gene lies in the $5^{\prime}$ end of $C D K N 2 B-A S 1$ and encodes two proteins, p16INK4A, and p14ARF that differ only in exon 1 due to alternative splicing. CDKN2B (cyclin dependent kinase inhibitor $2 \mathrm{~B}$ ) gene lies within exon 1 of $C D K N 2 B-A S 1$ in the antisense direction and encodes a p15INK4B protein (Supplementary Figure S1). These proteins are cyclin-dependent kinase inhibitors involved in cell cycle regulation, DNA damage, apoptosis, senescence, aging, extracellular matrix remodeling, and inflammation. Functional studies on CDKN2B-AS1 suggested that its function is tissue and cell type specific, and may depend on differential isoform expression of its transcripts. Knockdown of CDKN2B-AS1 is reported to result in premature senescence of vascular smooth muscle cells [25], and epithelial ovarian cancer cells [26], whereas it reduces or inhibits senescence in endothelial cells [27]. This variability in CDKN2B-AS1 transcript function highlights the need to studying its role in the ocular cell types to understand its significance in POAG pathogenesis.

Published studies have reported the association of the 9p21 locus with POAG mainly in Caucasian, Asian $[17,28]$ and only in a few Africans populations [29-31] (Supplementary Table S2) underlining the lack of diversity in previous studies. Moreover, these studies did not show the functional importance of this locus to POAG pathogenesis. In this study, we test the association of the SNP rs4977756 in $C D K N 2 B-A S 1$ with POAG and with endophenotypic traits in a large, deeply phenotyped AA cohort with POAG cases and controls. We investigate if the genomic region surrounding this SNP has a regulatory function. We characterize the expression of $C D K N 2 B-A S 1$ and its ability to regulate $C D K N 2 B$ and CDKN2A transcripts using relevant cell lines including HEK293T cells, human primary TM and human retinal tissues. Gene knockdown studies determine the function of CDKN2B-AS1 and its role in pathways relevant to POAG pathogenesis.

\section{Materials and Methods}

\subsection{Enrollment of the Study Subjects}

Subjects for this study were part of the Primary Open-Angle African American Glaucoma Genetics (POAAGG) cohort, which is a study investigating the genetic architecture of POAG in the over affected AA population. The POAAGG cohort includes self-identified African American individuals (Black, African decent, or Afro Caribbean), aged 35 years or older, from the Philadelphia region. Eligible patients were enrolled from ophthalmology clinics at the University of Pennsylvania (UPenn) and two external sites in West and North Philadelphia. Our study samples include AAs subjects with POAG $(n=1567)$ as cases and age and ethnicity matched healthy subjects without POAG $(n=1600)$ as controls. The race, age, family history, comorbidities and relevant medical history of all 
participants was recorded on a pre-designed questionnaire for clinical correlation. This study was approved by the UPenn institutional review board (IRB) and adhered to the Declaration of Helsinki. Subjects with co-morbid eye disease were excluded from the study. The diagnosis of POAG was based on patients having an open iridocorneal angle along with characteristic glaucomatous optic nerve findings corresponding to visual field loss. Blood and saliva samples from the subjects were collected in heparinized vacutainers (BD Biosciences, San Jose, CA, USA) by venipuncture with prior written informed consent and were immediately transferred to the laboratories in ice containers for genetic analysis [32].

\subsection{Molecular Genetic Analysis}

Genomic DNA was isolated from peripheral blood and saliva samples of the study participants using the phenol-chloroform method [33]. The DNA region (801 bp) containing the SNP rs4977756 in the CDKN2B-AS1 gene was amplified by a polymerase chain reaction (PCR) with gene specific primers followed by bidirectional sequencing (ABI3130xl, Applied Biosystems, Inc., Foster City, CA, USA). The association of genetic variants or SNP rs4977756 with POAG was assessed after determining the SNP status in all the study subjects using appropriate statistical tests. ANOVA analysis was performed on pooled case and control data to determine if the following continuous phenotypic variables related to POAG were associated with variation at this locus: IOP, central corneal thickness (CCT), vertical cup to disc ratio (VCDR), and retinal nerve fiber layer thickness (RNFL). A type 1 error rate of $\alpha=0.05$ was chosen to delineate significance for logistic regression and ANOVA analyses.

\subsection{Generation of Luciferase Reporter Constructs and Luciferase Reporter Assay}

Inserts containing the following genotypes at SNP rs4977756 (G/G; A/G; and A/A genotypes) within the $C D K N 2 B-A S 1$ region were amplified from genomic DNA isolated from study participants. To generate the A/G genotype from an insert containing the G/G genotype, we used QuikChange XL mutagenesis kit (Agilent Technologies, Santa Clara, CA, USA) as described previously [34]. Amplification of the inserts containing the A/A and G/G genotypes was performed using Phusion High-Fidelity DNA polymerase (NEB) and primers (5'-ACAAGAGCAGGATTGAGTCATGTA- $3^{\prime}$ and 5'-TGCATCTTTCTGTCAACTCCACTC-3') to produce four $2.7 \mathrm{~kb}$ DNA constructs surrounding SNP rs4977756 with the above-mentioned genotypes. An Acc65I restriction site was added to the sense primer and an EcoRV site to the antisense primer. Sequences containing the A/A, G/G, and A/G genotypes were each ligated into a pGL4.11 promoter vector and a pGL4.23 enhancer vector (Promega). The resulting plasmids were transformed into 10-beta Competent E. coli (High Efficiency) cells (NEB) and purified using GeneJET Plasmid Midiprep Kit (ThermoFisher). Plasmid sequences were confirmed using Sanger sequencing with Big Dye X Terminator (ThermoFisher).

Using a dual luciferase reporter assay, the enhancer and promoter activity of insert sequences containing A/A, A/G, and G/G were determined by transfecting HEK293T cells in triplicate along with positive and negative control expression vectors (empty pGL4.11 and pGL4.23 vectors). The pGL4.74 renilla luciferase vector (Promega) was co-transfected with experimental plasmids to control for transfection efficiency.

Briefly, HEK293T cells were transfected at approximately $60 \%$ confluency with the reporter plasmids using Lipofectamine 3000 (ThermoFisher), according to the manufacturer's instructions. Following transfection, the cells were incubated at $37^{\circ} \mathrm{C}$ with $5 \% \mathrm{CO}_{2}$ for $48 \mathrm{~h}$. Cells were subsequently lysed, and luciferase activity was measured by performing a Dual-Luciferase assay (Pierce) on transferred lysates in a 96-well white opaque bottomed luminometric plates (Falcon). Measurements obtained for firefly luciferase activity were divided by renilla luciferase activity to control for transfection efficiency, and normalized by the expression from empty vectors [34]. pRLU and empty-vector normalized luciferase expression results were compared by student's $t$-test for differential luciferase activity. 


\subsection{Cell Lines and Tissues Used for the Study}

The HEK293T (human embryonic kidney-CRL3216) cells were obtained commercially from ATCC and primary human trabecular meshwork (hTM) cells (Lot \# 3194) from Cell Applications. Characterization of TM cells was done by analyzing the MYOC gene expression after inducing dexamethasone (Supplementary Figure S2) as described previously [34]. All the cell lines used in our study were from passage 4 to passage 8 . Retinal tissues were surgically removed during evisceration surgery for POAG patients $(40.44 \pm 2.3, n=3)$ while control $(76 \pm 4.9, n=3)$ retina tissues were obtained from the donor eyes collected at Ramayamma International eye bank, L. V. Prasad Eye Institute, Hyderabad. The diagnosis of controls samples was confirmed from the history of the patients obtained from the family.

\subsection{Immunostaining}

For immunolocalization of CDKN2B, HEK293T and TM cells grown to $60-70 \%$ confluence in chamber slides were fixed with absolute methanol for $15 \mathrm{~min}$ in $-20{ }^{\circ} \mathrm{C}$ and then permeabilized by incubating with $0.5 \%$ Triton X in PBS for $5 \mathrm{~min}$ at room temperature. Blocking was carried out with $5 \%$ normal goat serum in $1 \%(w / v)$ BSA in 1X PBS for $60 \mathrm{~min}$ at room temperature. Thereafter, the slides were incubated for $60 \mathrm{~min}$ with rabbit Anti-p15INK4b antibody (ab53034) diluted to 1:100 in $0.1 \%$ BSA, followed by three washings with 1 X PBS. Further incubation was carried out with Alexa 594 anti-mouse secondary antibody for one hour. Cells were washed in 1X PBS and mounted with prolong gold mounting medium with DAPI for nuclei staining. Images were captured by Olympus FV1000 Confocal microscope with the use of appropriate filters and lasers [35].

\subsection{CDKN2B-AS1 siRNA Treatment}

TM cells were grown to approximately $80 \%$ confluence in 6-well plates. The cells were transfected with $10 \mathrm{nM}$ of pooled CDKN2B-AS1 siRNA (Dharmacon, Lafayette, CO, USA; Cat\# R-188105-00-0005) and $10 \mathrm{nM}$ of non-targeting control pool siRNA (Dharmacon Research; D-001320-10) using Lipofectamine RNAiMAX (Invitrogen, Carlsbad, CA, USA). After $72 \mathrm{~h}$, RNA was extracted from the transfected TMs and converted to cDNA using Superscript III reverse transcription kit (Life Technologies, Carlsbad, CA, USA) following manufacturer's instructions. Quantitative real-time PCR with gene specific primers was done following the methodology described below. These experiments were done in triplicate.

\section{7. $\beta$-Galactosidase Assay}

Senescence in TM cells was determined by using $\beta$-galactosidase staining kit (Cell Signaling Technology, Danvers, MA, USA). Briefly, TM cells at 80-90\% confluence were washed twice with 1X PBS to remove growth media and fixed in a fixative solution for 10-15 $\mathrm{min}$ at room temperature. Cells were washed twice with $1 \mathrm{X} \mathrm{PBS}$ and incubated in dark overnight at $37^{\circ} \mathrm{C}$ with fresh $\beta$-galactosidase staining solution. Stained cells were imaged under a light microscope and examined for the development of blue color.

\subsection{Treatment of Cells with TGF- $\beta 1$ and TGF- $\beta 2$}

Primary TM cells (Passage 6) at 70-80\% confluence were treated with $2.0 \mathrm{ng} / \mathrm{mL}$ activated rhTGF- $\beta 1$ and rhTGF- $\beta 2$ (R\&D Systems, Minneapolis, MN, USA) for $72 \mathrm{~h}$. The medium was replaced every $24 \mathrm{~h}$ with fresh medium containing recombinant human TGF- $\beta 1$ and TGF- $\beta 2$ (at a final concentration of $2 \mathrm{ng} / \mathrm{mL}$ ) and incubation was continued for a total of $72 \mathrm{~h}$. Cells treated with vehicle, $4 \mathrm{mM} \mathrm{HCl}$ containing $1 \%$ BSA was used as a control. 


\subsection{Semi-Quantitative PCR}

The RNA from untreated and treated TMs, HEK293 cells (using CDKN2B-AS1 siRNA and TGF $\beta$ induction) and POAG and normal eye tissues was extracted by the Trizol method (25). The cDNA was prepared using Superscript III One-Step RT-PCR kit (Invitrogen, Carlsbad, CA, USA). The RNA isolated from retinal tissues (POAG and normal retinal tissues) was converted to cDNA using verso cDNA synthesis kit (Thermo Scientific ${ }^{\mathrm{TM}}$, catalog no. AB1453B). A $10 \mu \mathrm{L}$ reaction mixture was made using iTaq ${ }^{\text {TM }}$ Universal SYBR ${ }^{\circledR}$ Green Supermix (BIO-RAD, Cat no. 38220090). Quantitative PCR was carried out using gene specific primers (Table $\mathrm{S} 1$ in Supplementary Material) for CDKN2B-AS1, $C D K N 2 B, C D K N 2 A, P 14 A R F, \beta$-actin and GAPDH. Pathway focused gene expression analysis was done using RT2 profiler PCR array (Human TGF $3 /$ BMP signaling, Cat\# PAHS-035Y, Human Extracellular Matrix and Adhesion Molecules Cat\#PAHS-013Z and Human Cellular Senescence Cat\# PAHS-050Z) following manufacturer's instruction.

\section{Results}

\subsection{Genotype-Phenotype Association Studies for SNP rs4977756}

The candidate SNP study for rs 4977756 revealed that the A allele reached nominal statistical significance, $p=0.042$, according to logistic regression analysis controlling for age and sex (Table 1 ). Additionally, analysis of the odds ratios (OR) for the genotypes suggested a recessive model of POAG risk for the risk allele A: OR $[A G]=1.02(0.80,1.30)$ and OR $[A A]=1.21(0.94,1.55)$. Therefore, we also performed logistic regression to determine the risk of POAG for patients harboring zero or one risk alleles versus those harboring two risk alleles. The association became more significant $(p=0.027)$, with an OR of 1.19 for homozygotes of the A allele (Table 2).

Table 1. Association between rs4977756 genotypes and Primary open-angle glaucoma (POAG) disease status (case vs. control). Analyses controlled for age and sex.

\begin{tabular}{cccccc}
\hline \multicolumn{2}{c}{ Locus | Genotype } & $\begin{array}{c}\text { Case } \\
\text { (Frequency) }\end{array}$ & $\begin{array}{c}\text { Control } \\
\text { (Frequency) }\end{array}$ & $\begin{array}{c}\text { Total } \\
\text { (Frequency) }\end{array}$ & $\begin{array}{c}\text { Age and Sex Adjusted } \\
\text { Odds Ratio (95\% CI) }\end{array}$ \\
\hline \multirow{3}{*}{ rs4977756 } & GG & $181(11.6 \%)$ & $199(12.4 \%)$ & $380(12.0 \%)$ & 1 \\
\cline { 2 - 6 } & AG & $691(44.1 \%)$ & $753(47.1 \%)$ & $1444(45.6 \%)$ & $1.02(0.80,1.30)$ \\
\cline { 2 - 6 } & AA & $695(44.4 \%)$ & $648(40.5 \%)$ & $1343(42.4 \%)$ & $1.21(0.94,1.55)$ \\
\cline { 2 - 6 } & Total & $1567(49.5 \%)$ & $1600(50.5 \%)$ & 3167 & \\
\hline
\end{tabular}

Age and Sex Adjusted (Logistic Regression) $p$-value: $0.042 *{ }^{*}$ denotes a significant result for $\alpha=0.05$.

Table 2. Association between rs4977756 genotypes and POAG disease status (case vs. control), according to a recessive model of POAG risk. Analyses controlled for age and sex. * denotes a significant result for $\alpha=0.05$.

\begin{tabular}{|c|c|c|c|c|c|}
\hline \multicolumn{2}{|c|}{ Locus |\# of Risk Alleles } & $\begin{array}{c}\text { Case } \\
\text { (Frequency) }\end{array}$ & $\begin{array}{c}\text { Control } \\
\text { (Frequency) }\end{array}$ & $\begin{array}{c}\text { Total } \\
\text { (Frequency) }\end{array}$ & $\begin{array}{c}\text { Age and Sex Adjusted } \\
\text { Odds Ratio (95\% CI) }\end{array}$ \\
\hline \multirow{3}{*}{ rs4977756 } & $\begin{array}{l}\text { 0-1 Risk Alleles } \\
\text { (GG or AG) }\end{array}$ & $872(55.7 \%)$ & $952(59.5 \%)$ & $1824(57.6 \%)$ & 1 \\
\hline & $\begin{array}{l}2 \text { Risk Alleles } \\
\text { (AA) }\end{array}$ & $695(44.3 \%)$ & $648(40.5 \%)$ & $1343(42.4 \%)$ & $1.19(1.02,1.39)$ \\
\hline & Total & $1567(49.5 \%)$ & $1600(50.5 \%)$ & 3167 & \\
\hline
\end{tabular}

Age and Sex Adjusted (Logistic Regression) $p$-value: $0.027^{*}$.

Analyses of the association between rs4977756 and quantitative POAG risk factors also yielded significant associations at $\alpha=0.05$. Prior to applying the recessive model of POAG risk for the A allele, 
ANOVA analysis revealed that the SNP rs4977756 was associated with CCT in a combined case-control analysis pool $(p=0.0299)$. Specifically, the AA genotype was associated with a thinner CCT than the GG and AG genotypes. When all three genotypes were considered in the ANOVA analysis, no other quantitative trait reached the threshold of statistical significance (Table 3).

Table 3. Relationship between rs4977756 genotypes and quantitative POAG risk factors. * denotes a statistically significant result $(\alpha=0.05)$.

\begin{tabular}{cccccc}
\hline \multicolumn{7}{c}{ rs4977756 } \\
\hline POAG Risk Factor & ANOVA $p$-Value & GG Mean (Std Dev) & AG Mean (Std Dev) & AA Mean (Std Dev) & All Genotypes \\
\hline Mean CCT & $0.03^{*}$ & $535.80(39.50)$ & $535.39(41.52)$ & $530.28(38.32)$ & $533.22(39.98)$ \\
\hline Mean IOP & 0.65 & $15.83(4.57)$ & $16.03(3.82)$ & $16.06(4.07)$ & $16.02(4.02)$ \\
\hline Mean VCDR & 0.1 & $0.54(0.25)$ & $0.54(0.25)$ & $0.56(0.25)$ & $0.55(0.25)$ \\
\hline Mean RNFL & 0.69 & $77.47(13.37)$ & $76.42(15.19)$ & $76.21(15.33)$ & $76.45(15.04)$ \\
\hline
\end{tabular}

However, when the recessive model for the A risk allele was used, we found that VCDR was also associated with the rs 4977756 locus in our study population $(p=0.0326)$. Additionally, the association between rs4977756 and CCT became stronger $(p=0.0081)$. This analysis suggests that individuals with the AA genotype have a significantly lower CCT measurements and greater VCDR measurements compared to individuals with the GG or AG genotype at rs4977756 (Table 4). We also performed multivariable linear regression to test the associations between rs4977756 (recessive model) and CCT and VCDR, controlling for age, sex, and disease status. The relationship between CCT and rs4977756 remained significant $(p=0.011)$, however the relationship between VCDR and rs4977756 did not reach significance $(p=0.261)$ (Table 4$)$.

Table 4. Relationship between rs4977756 recessive model and quantitative POAG risk factors. The bottom panel includes the p-values for the follow-up linear regression analyses for central corneal thickness (CCT) and vertical cup to disc ratio (VCDR) controlling for age, sex, and disease status. ${ }^{*}$ denotes a statistically significant result $(\alpha=0.05)$.

\begin{tabular}{ccccc}
\hline \multicolumn{5}{c}{ rs4977756 (0-1 vs. 2 Risk Alleles) } \\
\hline POAG Risk Factor & ANOVA $p$-Value & $\begin{array}{c}\text { 0-1 Risk Alleles } \\
\text { Mean (std dev) }\end{array}$ & $\begin{array}{c}\text { 2 Risk Alleles } \\
\text { Mean (std dev) }\end{array}$ & $\begin{array}{c}\text { All Genotypes } \\
\text { Mean (std dev) }\end{array}$ \\
\hline Mean CCT & $0.008^{*}$ & $535.48(41)$ & $530.28(38)$ & $533.22(39)$ \\
\hline Mean IOP & 0.65 & $15.99(3.99)$ & $16.06(4.07)$ & $16.02(4.02)$ \\
\hline Mean VCDR & $0.033^{*}$ & $0.54(0.25)$ & $0.56(0.25)$ & $0.55(0.25)$ \\
\hline Mean RNFL & 0.64 & $76.64(14.8)$ & $76.21(15.3)$ & $76.45(15)$. \\
\hline $\begin{array}{l}\text { Mean CCT Age, Sex, and Disease Status Adjusted (Linear Regression) } p \text {-value: } 0.011^{*} \text {. Mean VCDR Age, Sex, and } \\
\text { Disease Status Adjusted (Linear Regression) } p \text {-value: } 0.261 .\end{array}$
\end{tabular}

\subsection{Potential Regulatory Role of SNP rs4977756}

We observed an increased risk for POAG in patients with a homozygous A allele for SNP rs4977756. These findings were consistent with published studies [14,17]. In contrast, patients with the homozygous $\mathrm{G}$ allele have been previously shown to have increased risk of high-grade gliomas (excessive glial cell division and multiplication) [36]. These results suggest that this SNP region may have a regulatory role and can alter the expression of $C D K N 2 B-A S 1$ transcripts. Hence, we performed a luciferase reporter assay to understand the regulatory nature of this region. Analysis of the luciferase expression revealed that the region cloned upstream to the luciferase gene in the pGL4.11 promoter vector resulted in extremely low mean luciferase expression when compared to renilla luciferase expression and empty vector. This suggests the $2.4 \mathrm{~kb}$ DNA insert containing rs 4977756 is unlikely to be a promoter (Figure 1). 
a)

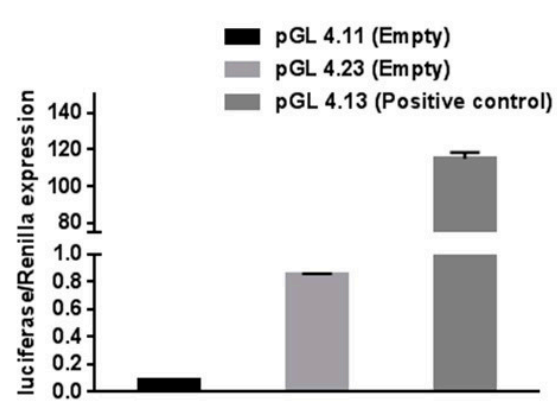

b)

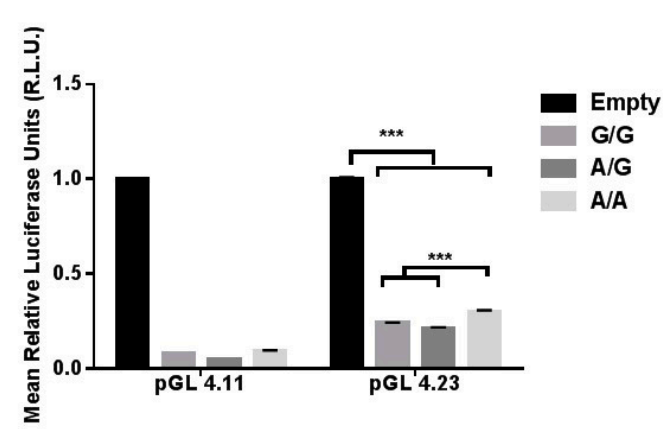

Figure 1. Luciferase Expression results for rs4977756 Genotypes. (a) Luciferase expression in promoter construct pGL4.11 (empty), pGL4.23 (empty) and pGL4.13 (SV40 promoter). (b). Mean pRLU-Normalized Luciferase Expression for rs4977756 genotypes. Mean luciferase expression from promoter construct vector pGL4.11 was very poor for all inserts. Each insert in the pGL4.23 response-element construct was associated with a reduction in mean luciferase expression compared to the empty pGL4.23 vector. All three $t$-tests comparing mean relative luciferase expression between the empty pGL4.23 vector and vectors containing inserts of varying genotypes (denoted with ${ }^{* * *}$ ) were statistically significant with $p$-values $<0.0001$.

When the genomic DNA with varying genotypes for rs4977756 were cloned downstream to a minimal promoter into the pGL4.23 repressor/enhancer construct, they exhibited a significant reduction in the mean luciferase expression when compared to the empty pGL4.23 vector, indicating that these regions may act as a repressor of luciferase gene expression (Figure 1). Specific genotypes within these inserts were associated with differing mean luciferase expression levels. There was no significant difference in mean luciferase expression between pGL4.23 inserts containing G/G and A/G genotypes. However, the A/A genotype was associated with significantly higher mean luciferase expression than the $\mathrm{A} / \mathrm{G}$ and $\mathrm{G} / \mathrm{G}$ genotype (Figure 1).

\subsection{Transcript Expression of CDKN2B-AS1 Locus in POAG Retina, TM and HEK293T Cells}

An increased risk for POAG in patients with SNP rs4977756 and repressor activity of the genomic region surrounding this SNP by luciferase reporter assays suggests that this region may be functionally relevant to glaucoma pathogenesis. We observed a significant increase in the expression of $C D K N 2 A$ $(p=0.011)$ and $C D K N 2 B(p=0.002)$ transcripts in POAG retina when compared to normal/control retina, further supporting their involvement in POAG pathogenesis (Figure 2a). We also determined the endogenous expression of $C D K N 2 B-A S 1$ and its nearby genes $C D K N 2 B$ and $C D K N 2 A$ in HEK293T and TM cells. Expression of CDKN2A, CDKN2B and CDKN2BAS1 transcripts are quite similar in HEK293T and TM cells. However, there was higher expression of CDKN2BAS1 in HEK 293T cells as compared to TM cells. Interestingly, $C D K N 2 A$ transcript was abundantly expressed when compared to CDKN2B in HEK293T and TM cells (Figure 2b).

\subsection{CDKN2B-AS1 Regulates the Expression of CDKN2B and CDKN2A Transcripts}

Published studies on peripheral blood cells in diabetes, cardiac diseases and cancers showed the regulatory effect of $C D K N 2 B-A S 1$ on the expression of $C D K N 2 A$ and $C D K N 2 B$ transcripts [37]. However, this regulatory potential of $C D K N 2 B-A S 1$ has not been tested in ocular cell lines and tissues. Hence, we used siRNA knockdown studies to determine if the CDKN2B-AS1 knockdown affects cis-gene expression. Real-time qRT-PCR analysis showed efficient knockdown of $C D K N 2 B-A S 1$ by the pooled $10 \mathrm{nM} C D K N 2 B-A S 1$ siRNAs in both TM and HEK293T cells when compared to cells transfected with non-targeting control siRNA (Figure 3). Knockdown of CDKN2B-AS1 resulted in significant increase in CDKN2B expression in HEK293T cells (Figure 3a,c). A marked increase in CDKN2B expression was also observed in TM cells after $10 \mathrm{nM} C D K N 2 B-A S 1$ siRNA treatment as assessed by immunocytochemistry and RT-PCR (Figure $3 b, c)$. No significant change in CDKN2A and $p 14 A R F$ expression was observed 
in TMs and HEK293T cells after CDKN2B-AS1 suppression. Taken together, CDKN2B-AS1 siRNA knockdown has similar effects on the expression of $C D K N 2 A, C D K N 2 B$ and $p 14 A R F$ genes in TM and HEK293T cells, but with varying intensity.

a)

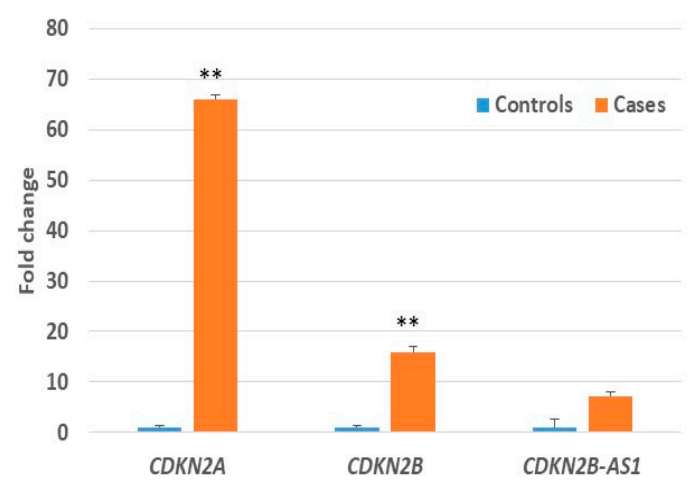

b)

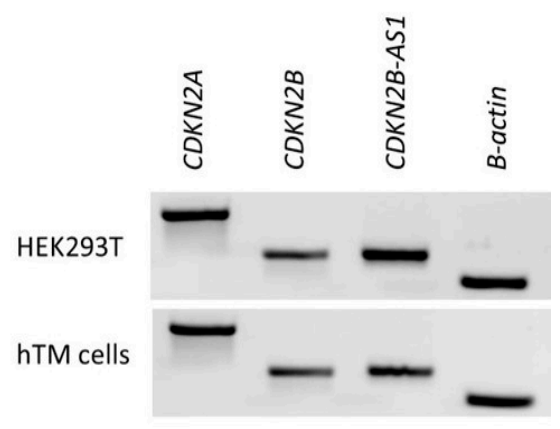

Figure 2. Expression of $C D K N 2 A, C D K N 2 B$ and $C D K N 2 B-A S 1$ transcripts in ocular tissue and cells in (a) expression in POAG $(n=3)$ and control retina $(n=3)$ and $(\mathbf{b})$ human trabecular meshwork (hTM) and Human embryonic kidney 293 T (HEK293T) cell lines. ${ }^{\text {*** }}$ signifies $p<0.005$.

a)

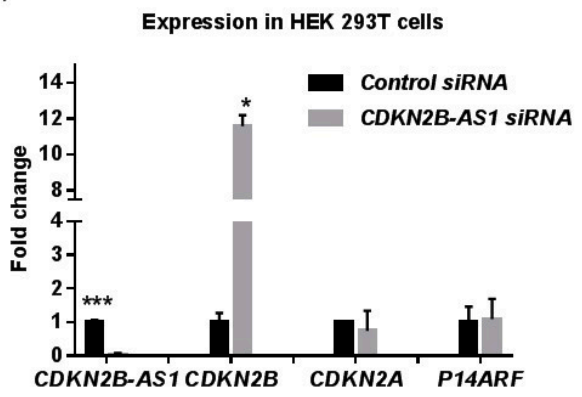

b)

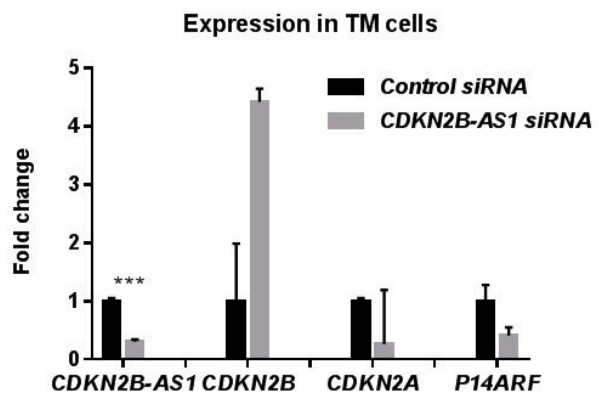

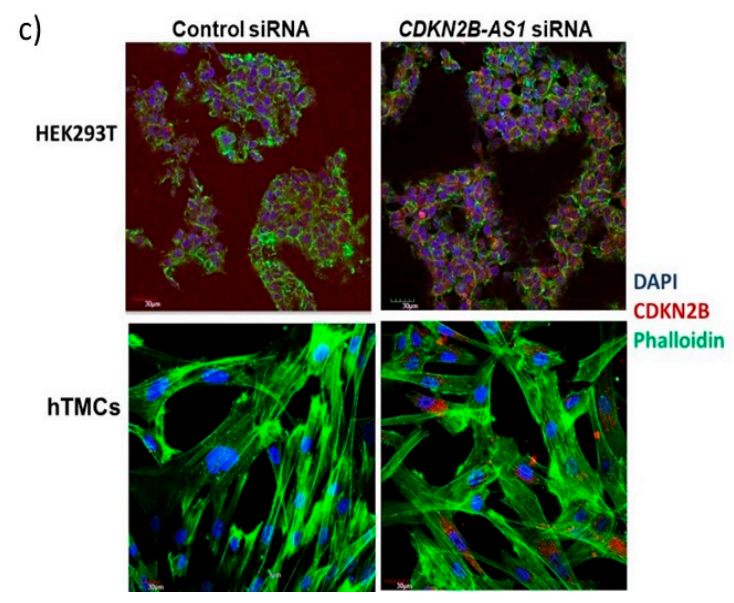

Figure 3. CDKN2B-AS1 siRNA mediated knockdown in HEK293T and trabecular meshwork (TM) cells. (a,b) Relative quantification of $C D K N 2 B-A S 1, C D K N 2 B, C D K N 2 A$ and P14ARF transcript in HEK293T and TM cells after CDKN2B-AS1 siRNA $(10 \mathrm{~nm})$ treatment when compared to control siRNA $(10 \mathrm{~nm})$ treatment for $72 \mathrm{~h}$; (c) Representative cultures established after CDKN2B-AS1 and control siRNA treatment demonstrated increased CDKN2B (red) detection in phalloidin (green) stained HEK293T and TM cells. (Scale bar represents $30 \mu \mathrm{m}$; ${ }^{* * *}$ denotes $p<0.001$; ${ }^{*}$ denotes $p<0.01$, Bar graphs illustrate fold change $\left.\left(2^{-\triangle \Delta C T}\right) \pm S E M\right)$. 


\subsection{Role of CDKN2B-AS1 in Causing Cellular Senescence and ECM Homeostasis}

Accumulation of cells expressing cellular senescence markers were found to be associated with several age-related diseases including POAG. Published studies reveal the potential role of accumulation of senescent TM cells in the pathophysiology of the aqueous humor outflow pathway function [38]. In vitro experiments showed the effect of CDKN2B-AS1 knockdown in increased apoptosis and senescence, while its overexpression reversed the phenotype in cancer cells [39]. In the present study, increased expression of senescence pathway genes (Figure 4a) was observed in TM cells after $C D K N 2 B-A S 1$ siRNA treatment when compared to the TM cells treated with non-targeting control siRNA using RT2 profiler array. $C D K N 2 B-A S 1$ suppression resulted in a significant increase in senescence initiators pathways including interferon signaling (CDKN1A, CDKN1B, and ALDH1A3), insulin growth factor (IGFBP5, IGF1R, IGFBP3) and p53/pRB signaling genes (ING1, ID1, PLAU, $C D K N 1 C, S P A R C$ and $C D K N 2 B$ ) (Figure $4 \mathrm{~b}$ ). Significantly, increased expression of cell adhesion molecules in TM cells (CD44, ICAM1, CTNNA1, CTNND1, LAMA1, LAMC1, SPARC, ITGA3, ITGA5 and ITGA8) after CDKN2B-AS1 siRNA treatment (Figure 4c) supported the presence of senescent environment in TM cells [37-42]. Presence of increased number of SA- $\beta$-Gal positive TM cells after $C D K N 2 B-A S 1$ treatment, when compared to non-targeting control siRNA, confirmed the senescent phenotype. This data further defines the role of CDKN2B-AS1 in regulating senescence (Figure 4d).

In addition, senescent cells altered the extracellular matrix (ECM) composition by increased expression and degradation of extracellular matrix metalloproteinase, leading to the accumulation of ECM products that may have deleterious effects in tissue physiology. Moreover, stiffening of TM cells is the hallmark of glaucoma and is believed to be induced by ECM deposition. Significant increased expression of ECM molecules ECM1, COL7A1, COL12A1, COL15A1, COL16A1, COL1A1, and COL6A2 along with MMPs suggests an accumulation of ECM products in TM cells after CDKN2B-AS1 suppression (Figure 4e). Increase in senescent cells and ECM deposition may affect the TM cell integrity resulting in functional alteration and increased outflow resistance, which may lead to RGC death, thereby contributing to the development or progression of POAG.

\subsection{TGF- $\beta$ Signaling in Senescent-Inflammatory Phenotype}

The TGF $\beta$ signaling pathway is of particular interest in glaucoma, since functional studies have shown the role of elevated TGF $\beta 1$ signaling in inflammation, senescence and ECM deposition in TM cells, lamina cribrosa (LC), and aqueous humor of glaucomatous eyes $[13,40,41]$. Knockdown of CDKN2B-AS1 increased the expression of $\mathrm{p} 15$ (INK4b) and transforming growth factor $\beta 1$ (TGF $\beta 1$ ) resulting in the inhibition of cellular proliferation in human esophageal squamous cell carcinoma [42]. This study suggested the role of TGF $\beta 1$ signaling in CDKN2B-AS1 mediated regulation in cell proliferation. Therefore, to understand the role of TGF $\beta 1-C D K N 2 B-C D K N 2 B-A S 1$ axis in glaucoma pathogenesis, we investigated the effect of $C D K N 2 B-A S 1$ knockdown and TGF $\beta 1 / T G F$ 2induction on this axis. Knockdown of $C D K N 2 B-A S 1$ transcript resulted in an increase of TGF $\beta 1$ and $C D K N 2 B$ transcript expression in TM cells (Figure 5 a). Quantitative gene expression profiles showed a significant increase in TGF $\beta$ signaling genes like CDKN1A, IGFBP3, MYC, ID1, FAS and UBASH3B involved in cellular senescence; BMP1, COL1A1, COL1A2, TGFBI involved in ECM deposition and other signaling genes SMURF1 and HERPUD1 in TM cells after CDKN2B-AS1 suppression (Figure 5a). Downregulation of TGF $\beta$ signaling regulators/inhibitors, i.e., NDR1, BMB1, PLAU, SERPINE1 and THBS1 (Figure 5a), further strengthened our hypothesis that increased TGF $\beta$ signaling mediates senescence and fibrosis after $C D K N 2 B-A S 1$ suppression.

Furthermore, induction of TM cells with TGF $\beta 1$ and TGF $\beta 2$ resulted in a significant increase in $C D K N 2 B$ along with a slight increase in $C D K N 2 B-A S 1$ (Figure $5 b, c)$. We observed a significant increase in inflammatory cytokines IL1a and IL6 and increase in TNF $\alpha$ when compared to vehicle induced TM cells, suggesting the role TGF $\beta$ mediated inflammation in TM cells (Figure $5 \mathrm{~d}$ ). Thus, our results demonstrate the role of increased TGF $\beta$ signaling in cellular senescence, fibrosis and inflammation in 
TM cells. Although, TGF $\beta$ may not be in tight regulation with $C D K N 2 B-A S 1$, our results show that it plays a role in $C D K N 2 B-C D K N 2 B-A S 1$ mediated cellular senescence and inflammation.

a)

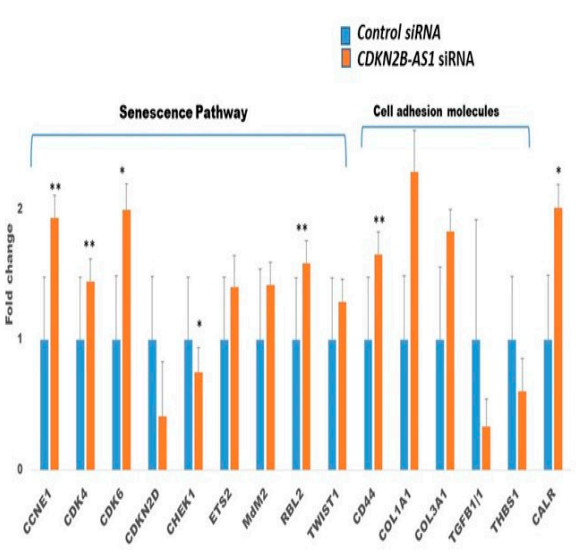

c)

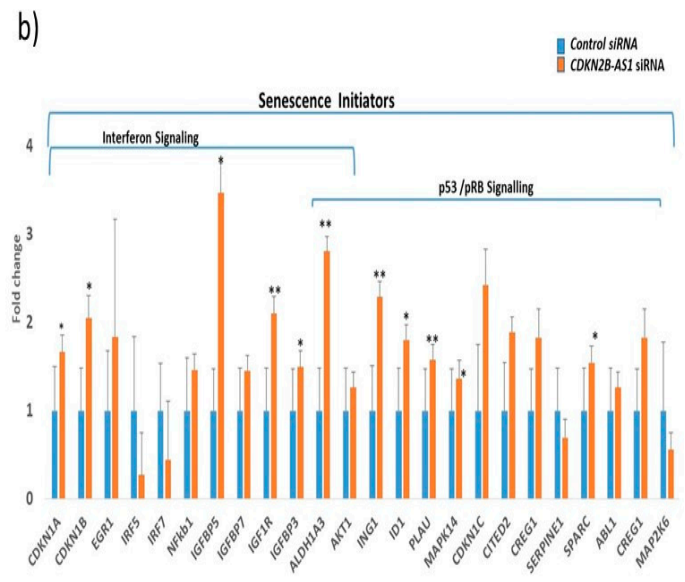

d)

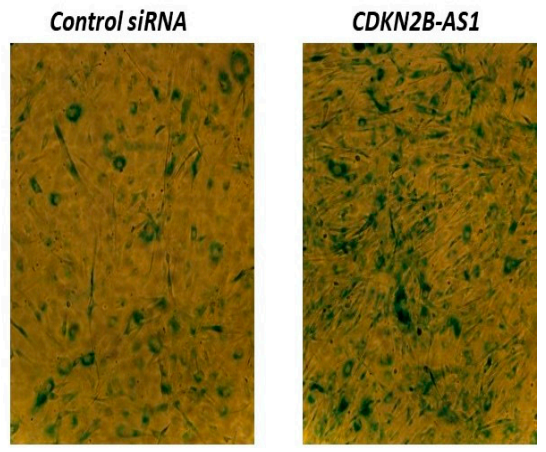

e)

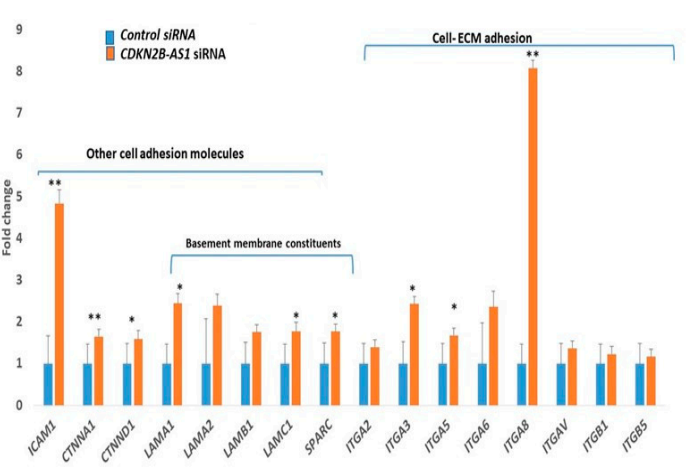

Control siRnA

CDKN2B-AS1 SIRNA

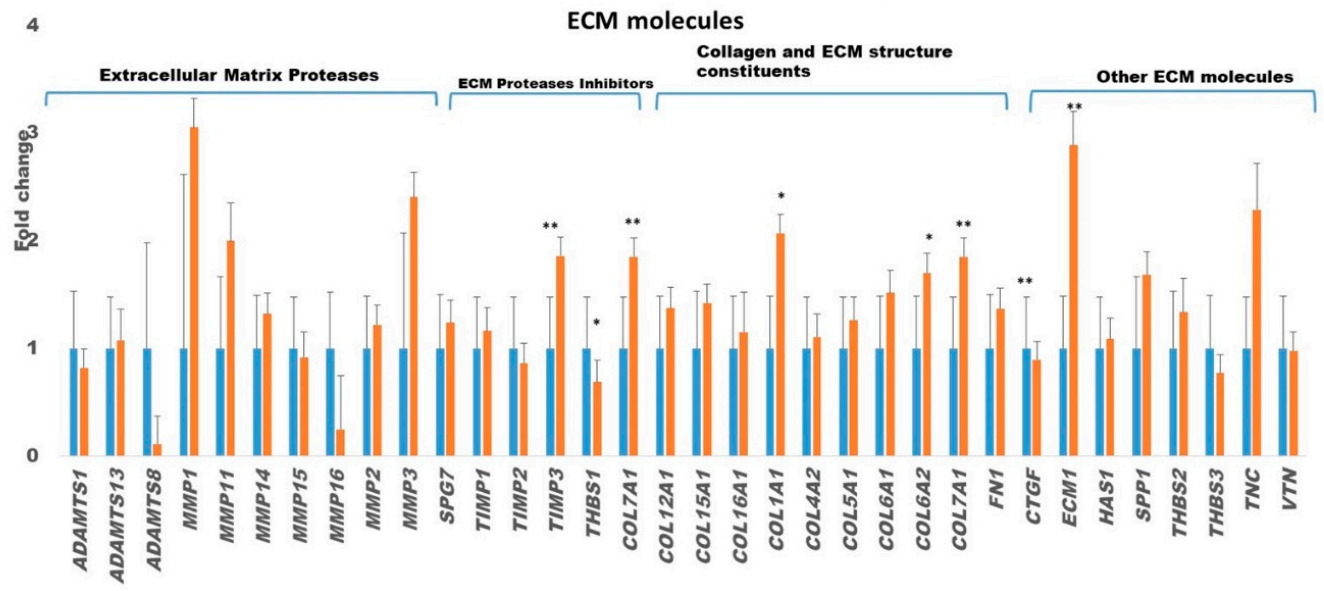

Figure 4. Cellular senescence in TM cells after suppression of CDKN2B-AS1. (a-c,e) The human cellular senescence and extracellular matrix and adhesion molecules RT $^{2}$ Profiler PCR arrays showed differential gene expression profile in TM cells after $10 \mathrm{nM} C D K N 2 B-A S 1$ siRNA and control siRNA treatment for $72 \mathrm{~h}$. Bar graphs illustrate fold change $\left(2^{-\Delta \Delta C T}\right) \pm S E M$. Asterisks indicate significance of difference from controls ${ }^{* *} p<0.05, * p<0.005$, (d) Senescence-related $\beta$-galactosidase staining of TM cells after $10 \mathrm{nM} C D K N 2 B-A S 1$ siRNA and control siRNA treatment. Blue color stained cells are $\beta$-galactosidase positive cells indicates senescence. Magnification $10 \times$. 
a)

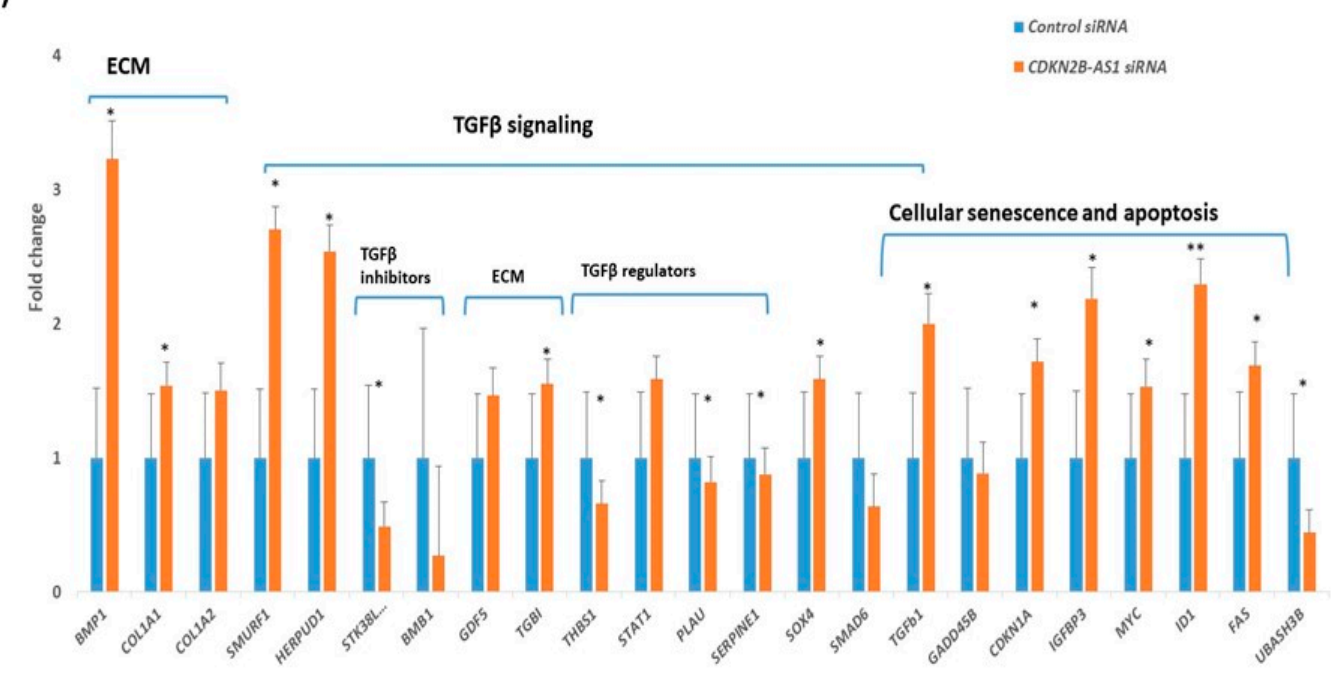

b)

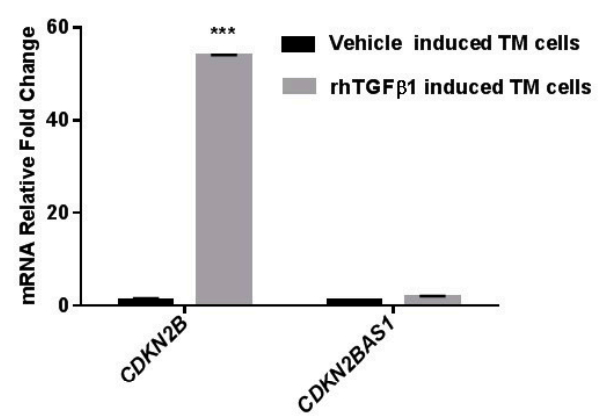

d)

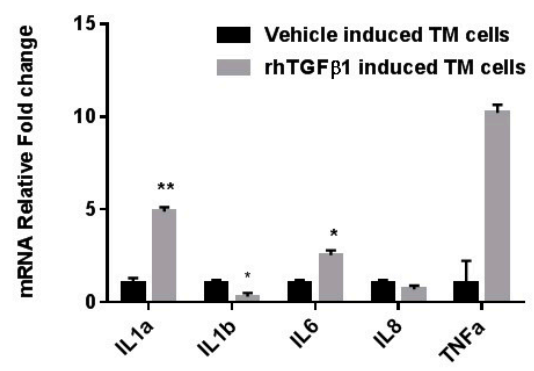

c)

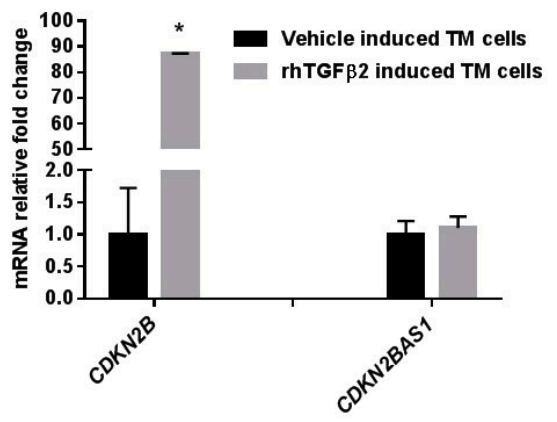

Figure 5. $C D K N 2 B-A S 1$ mediated senescence and inflammatory cytokine secretion via TGF $\beta$ signaling. (a) The human TGF $\beta$ BMP Signaling Pathway RT2 Profiler PCR arrays showed differential gene expression profile in TM cells after $10 \mathrm{nM} C D K N 2 B-A S 1$ siRNA and control siRNA treatment for $72 \mathrm{~h}$. $(\mathbf{b}, \mathbf{d}) \mathrm{TM}$ cells were treated with vehicle or $2.0 \mathrm{ng} / \mathrm{mL}$ activated $\mathrm{rhTGF} \beta 1$ for 3 days. (c) TM cells were treated with vehicle or $2.0 \mathrm{ng} / \mathrm{mL}$ activated rhTGF $\beta 2$ for 3 days. $\beta$-actin normalized transcript levels for CDKN2B, CDKN2B-AS1, inflammatory cytokines (IL1a, IL1b, Il6, IL8 and TNFa) in TGF $\beta$ induced hTM cells relative to control as detected by qPCR. Bar graphs illustrate fold change $\left(2^{-\Delta \Delta C T}\right) \pm \mathrm{SEM}$. Asterisks indicate significance of difference from controls; ${ }^{* * *} p<0.05,{ }^{* *} p<0.005,{ }^{*} p<0.005$.

\section{Discussion}

This study demonstrated that the CDKN2B-AS1 involved in mediating senescence, inflammation, and ECM accumulation and may play an important role in the development of POAG. We showed that the intronic region of $C D K N 2 B-A S 1$ harboring the allele A at SNP rs4977756 was associated with an increased risk for POAG in AAs. Our results agree with findings reported in populations of European descent $[14,28]$, but to the best of our knowledge, this SNP has not previously been associated 
with POAG in an AA cohort. Moreover, previous studies on African populations have identified an association of SNPs in the 9p21 locus with POAG (although reported SNPs differed) [31] suggesting that this locus is driving risk of POAG in AAs as in other populations. However, it is important to consider that, unlike Europeans, lack of a larger sample size could be a reason for nominal associations of rs4977756 with POAG in Africans and African descent samples [31].

It was interesting to note that the recessive model at rs4977756 resulted in stronger associations between POAG risk factors (CCT and VCDR). The 9p21 locus is known to be associated with normal tension glaucoma and various optic disc parameters, including CDR, but is not a genetic predictor of CCT $[28,43]$. CCT is an independent risk factor for the development of POAG, such that patients with a thinner CCT at a relatively elevated risk for developing POAG, regardless of their IOP. This correlation led to the hypothesis that a thinner CCT may be a biomarker of structural or ECM abnormalities found within the TM or ONH. This idea was further supported by our functional studies in TMs where knockdown of CDKN2B-AS1 resulted in significant disruption in ECM homeostasis. Although we did not quantify CCT thickness in AAs, it was interesting that SNP rs4977756 in CDKN2B-AS1 was strongly associated with CCT and VCDR, but not IOP.

It is hypothesized that the intronic region containing rs4977756 may possess response elements that affect the expression of CDKN2B-AS1 and its sense transcripts [31]. Interestingly, eQTL studies in lymphoblastic cell lines have shown that rs4977756 genotypes significantly affect the expression of the non-adjacent gene, dehydrogenase/reductase 9 (DHRS9) (i.e., trans-regulation) [24]. DHRS9 participates in the metabolism of all-trans retinoic acid in neurons and astrocytes, and can also serve as a nuclear transcriptional repressor [44]. Our luciferase assay results demonstrated that the intronic region surrounding rs4977756 contains regulatory response elements more specifically, likely to serve as transcriptional repressors. Our results also suggested that specific allele combinations at rs4977756 may fine-tune the repressor activity in this region, as inserts containing the $\mathrm{A} / \mathrm{G} \mathrm{rs} 4977756$ genotype exhibited less luciferase expression that the G/G and A/A genotypes. Further, we used the bioinformatics tool MATCH to predict whether the short segment containing rs4977756 loci might represent known transcription factor binding motifs [45]. According to MATCH, the COMP1 transcription factor was repeatedly implicated to bind rs 4977756 loci. COMP1 is relatively understudied, but it is thought to regulate inflammatory responses [45]. These transcription binding sites may affect inflammatory responses and senescence that correspond well to the senescent-inflammatory phenotype of POAG previously described [13].

Disease associated variants have been reported to result in differential transcript expression of $C D K N 2 A, C D K N 2 B$ and $C D K N 2 B-A S 1$ [46,47]. Cardiac artery disease (CAD) associated risk-SNPs increased $C D K N 2 B-A S 1$ isoform expression in human endothelial cell lines, macrophage cell cultures and coronary smooth muscle cells [48], while a reduction of CDKN2B-AS1 and CDKN2A expression increased $C D K N 2 B$ expression in peripheral blood cells [37]. The present study is an attempt to test the expression of CDKN2B-AS1,CDKN2B and CDKN2A/ARF in TM cells, which are one of the primary cells affected in POAG, and to correlate their functions with downstream pathway regulation. So far three novel CDKN2B-AS1 splice variants have been reported in the human retina [14] and (in Ensemble genome browser), $28 C D K N 2 B-A S 1$ splice variants are reported, with exons 1 and 6 coinciding in most of them. Therefore, a pool of four siRNAs targeting exon 1, 2 and 6 were used for CDKN2B-AS1 knockdown studies in HEK 293T cells and TMs, which resulted in the efficient suppression of $C D K N 2 B-A S 1$ expression.

We observed that the suppression of $C D K N 2 B-A S 1$ resulted in the upregulation of $C D K N 2 B$ in TMs and HEK292T cells, which are in accordance with previous reports in vascular smooth muscle cells [49] and cancer cell lines [50]. We did not observe any significant change in the CDKN2A or p14ARF expression following knockdown of $C D K N 2 B-A S 1$ transcripts. These findings are consistent with Kotake et al. study suggesting the involvement of polycomb repression complex mechanism in the regulatory role of $C D K N 2 B-A S 1$ in an ocular cell line [50]. This mechanism postulated that 
CDKN2B-AS1 serves as a scaffold for the chromatin modifying complexes PRC1 and PRC2, mediating the repression in cis of the INK4b-ARF-INK4a locus [50,51].

It is well established that $C D K N 2 B-A S 1$ plays a regulatory role in senescence and apoptosis through several pathways involved in the cell cycle including DNA damage, apoptosis and inducing a senescence associated secretory phenotype [52]. Signaling pathways, i.e., retinoblastoma protein (pRB) and protein 53 (p53), regulate cell division via CDKN2A and CDKN2B resulting in cellular senescence. Increased expression of p53/p21 signaling and $\mathrm{pRB} / \mathrm{p} 16$ has been reported to induce premature senescence due to down regulation of CDKN2B-AS1 [53]. The CDKN2B-AS1 knockdown studies in TM cells may have resulted in premature senescence due to increased gene expression in the above pathways (Figure 4). CDKN2B-AS1 also influences cell growth by repression of the TGF $\beta /$ Smad signaling pathway [42]. In the present study, CDKN2B-AS1 knock down resulted in the increase in TGF $\beta 1$ signaling, mediating increase in expression of cellular senescence genes, ECM genes and decrease in expression of TGF $\beta$ regulators and inhibitors. The TGF $\beta$ induction in TM cells did not correlate directly with $C D K N 2 B-A S 1$ mediated cellular senescence, suggesting that TGF $\beta$ signaling in cell regulation relies upon a balance of the signaling inputs from other genes, growth factors and cytokines [54]. In POAG, it is most likely that genetic or aging related gene expression changes to $C D K N 2 B-A S 1-C D K N 2 B$ axis may lead to cellular senescence associated alteration in secretome and cytokines, which leads to increase TGF $\beta 1$ signaling mediated senescent-inflammatory phenotype or vice versa (Figure 6).

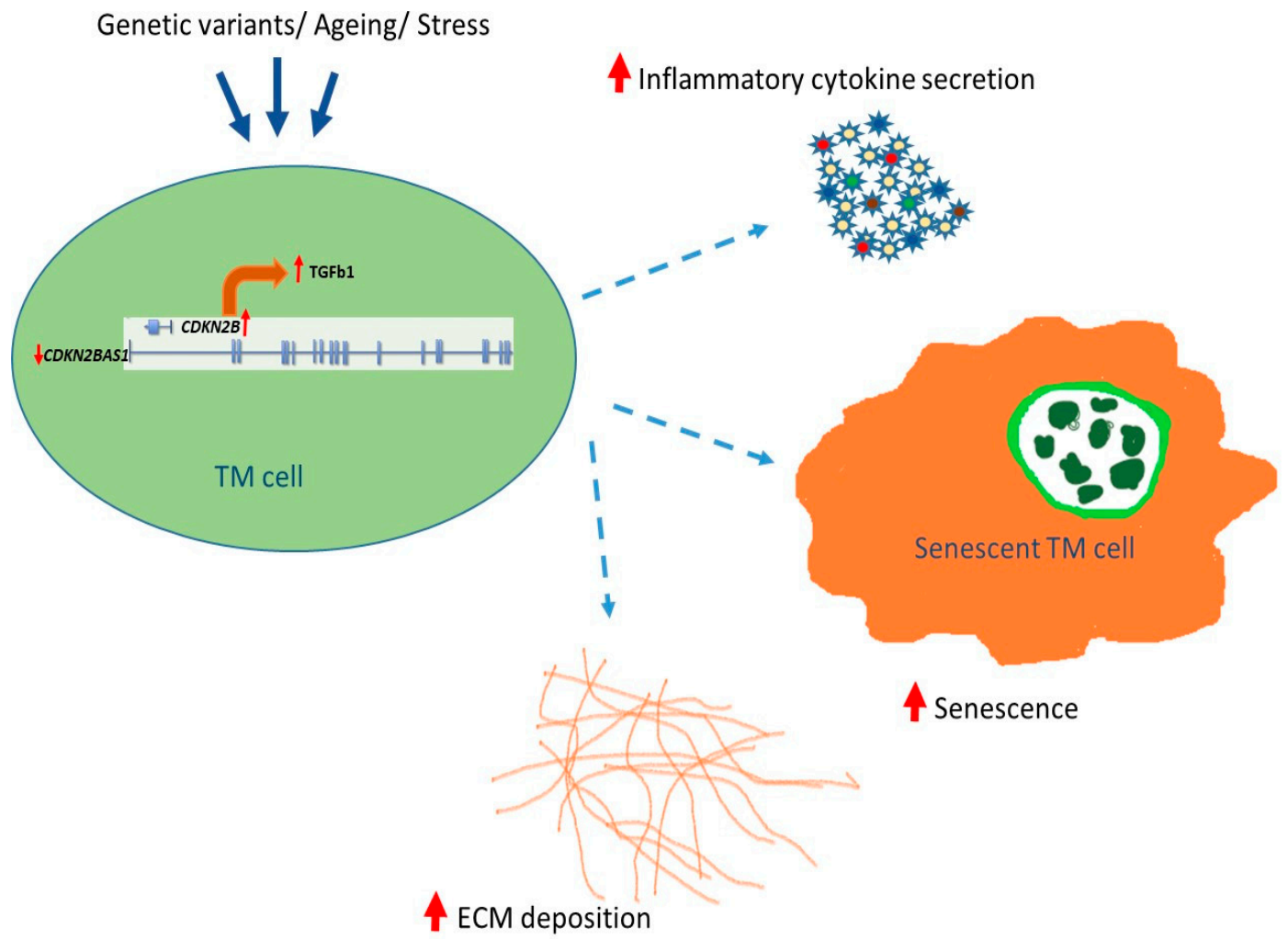

Figure 6. Schematic of the proposed mechanism of CDKN2B-AS1 knockdown mediated senescenceinflammatory phenotype in TM cells. Genetic variants, aging and oxidative or other stress could result in the downregulation of $C D K N 2 B-A S 1$, resulting in increased expression of $C D K N 2 B$ (cell cycle arrest gene). $C D K N 2 B$ directly or via TGF $\beta$ signaling increases ECM deposition, cellular senescence and secretion of inflammatory cytokines in TM cells. Together, these will contribute to increased outflow resistance and TM cell death leading to POAG pathogenesis.

In conclusion, current findings appear to support that at least some POAG associated SNPs (and unassociated SNPs in relative LD) in 9p21 locus may have regulatory roles that could potentially 
translate to altered expression of genes in this locus in a cell specific and tissue specific manner. Significant increased expression of $C D K N 2 A$ and $C D K N 2 B$ was observed in POAG retinal tissues, further signifying the involvement of this locus in POAG pathogenesis. Our data further suggests that the complex interplay between the genes/molecules regulated by $C D K N 2 B-A S 1-C D K N 2 B$ axis (9p21 region) in TM cells may play an important role in inflammation, senescence and tissue remodeling (Figure 6). Further experimentation is warranted in RGCs and POAG tissues to better elucidate the exact nature of the interactions between genes in this locus that may lead to RGC death in POAG. Understanding the ocular cell type specific expression and regulation of $C D K N 2 B-A S 1-C D K N 2 B$ axis may be the first step towards the understanding of this complex mechanism in POAG pathogenesis. Much remains to be learned about the CDKN2BAS1-CDKN2B transcript/isoform expression in ocular cell types and how these different isoforms influence tissue homeostasis to modulate disease risk. A better understanding of these complex mechanisms could have a profound translational impact, in slowing the development of POAG by intervening in neuro-inflammation, tissue remodeling, and cell death.

Supplementary Materials: The following are available online at http://www.mdpi.com/2073-4409/9/9/1934/s1, Figure S1: Schematic representation showing CDKN2B-AS1, CDKN2B and CDKN2A gene and location of rs4977756 (indicated by arrowhead) within $C D K N 2 B-A S 1$ gene; Figure S2: Western blot showing the induction of Myocilin in TM cultures (P2 to P4 cultures) with $100 \mathrm{mM}$ Dexamethasone treatment for 3 days; Table S1: Primers sequence used for real-time RT-PCR analysis of CDKN2B-AS1, CDKN2B, CDKN2A and $p 14 A R F$ genes in human retina and HEK293T and TM cells. F = Forward primer, $\mathrm{R}=$ Reverse primer; Table S2: Comprehensive list SNPs associated with POAG in 9p21 locus in diverse populations.

Author Contributions: Conceptualization, J.M.O. and V.R.M.C.; data curation, S.R., I.D., H.V.G., L.V., M.P. and I.K.; formal analysis, S.R., I.D. and S.V.; funding acquisition, I.K., J.M.O. and V.R.M.C.; investigation, S.R., L.V., S.V. and V.R.M.C.; methodology, S.R., I.D., H.V.G., L.V., M.P., S.V. and T.V.D.; resources, T.V.D.; supervision, I.K., J.M.O. and V.R.M.C.; validation, S.R., I.D., H.V.G., M.P. and T.V.D.; writing-original draft, S.R., I.D., M.P., I.K. and V.R.M.C.; writing-review and editing, S.R., H.V.G., M.P., I.K. and J.M.O. All authors have read and agreed to the published version of the manuscript.

Funding: This research was funded by the National Eye Institute of the National Institutes of Health under Award Number R21EY028273-01A1 (VRMC), and 1RO1EY023557-01 (JMO), Research to Prevent Blindness Unrestricted Grant Funds to Scheie Eye Institute (VRMC, and JMO), F.M. Kirby Foundation, and The Paul and Evanina Bell Mackall Foundation Trust for their support The Center for Advanced Retinal and Ocular Therapeutics (CAROT), The Foundation for Fighting Blindness (FFB), Research to Prevent Blindness (RPB), the National Institute of Health vision core grant P30EY01583-26, National Institutes of Health, Department of Health and Human Services, under eyeGENE ${ }^{\mathrm{TM}}$ and contract Nos. HHSN260220700001C and HHSN263201200001C. IK was supported by Department of Biotechnology, Ministry of Science and Technology, Government of India (BT/PR32404/MED/30/2136/2019).

Acknowledgments: The authors would like to sincerely thank Rebecca Salowe for her diligent proofreading of this manuscript and Sirisha Senthil for her assistance with procurement of human eye tissues used in this study.

Conflicts of Interest: The authors declare no conflict of interest.

\section{References}

1. Mahabadi, N.; Foris, L.A.; Tripathy, K. Open Angle Glaucoma. In StatPearls; StatPearls Publishing: Treasure Island, FL, USA, 2020.

2. Beidoe, G.; Mousa, S.A. Current primary open-angle glaucoma treatments and future directions. Clin. Ophthalmol. 2012, 6, 1699-1707. [CrossRef] [PubMed]

3. Rudnicka, A.R.; Mt-Isa, S.; Owen, C.G.; Cook, D.G.; Ashby, D. Variations in primary open-angle glaucoma prevalence by age, gender, and race: A Bayesian meta-analysis. Investig. Ophthalmol. Vis. Sci. 2006, 47, 4254-4261. [CrossRef] [PubMed]

4. Friedman, D.S.; Wolfs, R.C.; O'Colmain, B.J.; Klein, B.E.; Taylor, H.R.; West, S.; Leske, M.C.; Mitchell, P.; Congdon, N.; Kempen, J.; et al. Prevalence of open-angle glaucoma among adults in the United States. Arch. Ophthalmol. 2004, 122, 532-538. [CrossRef] [PubMed]

5. Tielsch, J.M.; Sommer, A.; Katz, J.; Royall, R.M.; Quigley, H.A.; Javitt, J. Racial variations in the prevalence of primary open-angle glaucoma. The Baltimore Eye Survey. JAMA 1991, 266, 369-374. [CrossRef] 
6. Vitart, V.; Bencic, G.; Hayward, C.; Skunca Herman, J.; Huffman, J.; Campbell, S.; Bucan, K.; Navarro, P.; Gunjaca, G.; Marin, J.; et al. New loci associated with central cornea thickness include COL5A1, AKAP13 and AVGR8. Hum. Mol. Genet. 2010, 19, 4304-4311. [CrossRef]

7. Lu, Y.; Dimasi, D.P.; Hysi, P.G.; Hewitt, A.W.; Burdon, K.P.; Toh, T.; Ruddle, J.B.; Li, Y.J.; Mitchell, P.; Healey, P.R.; et al. Common genetic variants near the Brittle Cornea Syndrome locus ZNF469 influence the blinding disease risk factor central corneal thickness. PLoS Genet. 2010, 6, e1000947. [CrossRef]

8. Macgregor, S.; Hewitt, A.W.; Hysi, P.G.; Ruddle, J.B.; Medland, S.E.; Henders, A.K.; Gordon, S.D.; Andrew, T.; McEvoy, B.; Sanfilippo, P.G.; et al. Genome-wide association identifies ATOH7 as a major gene determining human optic disc size. Hum. Mol. Genet. 2010, 19, 2716-2724. [CrossRef]

9. Cornes, B.K.; Khor, C.C.; Nongpiur, M.E.; Xu, L.; Tay, W.T.; Zheng, Y.; Lavanya, R.; Li, Y.; Wu, R.; Sim, X.; et al. Identification of four novel variants that influence central corneal thickness in multi-ethnic Asian populations. Hum. Mol. Genet. 2012, 21, 437-445. [CrossRef]

10. Khor, C.C.; Ramdas, W.D.; Vithana, E.N.; Cornes, B.K.; Sim, X.; Tay, W.T.; Saw, S.M.; Zheng, Y.; Lavanya, R.; $\mathrm{Wu}, \mathrm{R}$.; et al. Genome-wide association studies in Asians confirm the involvement of ATOH7 and TGFBR3, and further identify CARD10 as a novel locus influencing optic disc area. Hum. Mol. Genet. 2011, 20, 1864-1872. [CrossRef]

11. Vithana, E.N.; Aung, T.; Khor, C.C.; Cornes, B.K.; Tay, W.T.; Sim, X.; Lavanya, R.; Wu, R.; Zheng, Y.; Hibberd, M.L.; et al. Collagen-related genes influence the glaucoma risk factor, central corneal thickness. Hum. Mol. Genet. 2011, 20, 649-658. [CrossRef]

12. Ramdas, W.D.; van Koolwijk, L.M.; Ikram, M.K.; Jansonius, N.M.; de Jong, P.T.; Bergen, A.A.; Isaacs, A.; Amin, N.; Aulchenko, Y.S.; Wolfs, R.C.; et al. A genome-wide association study of optic disc parameters. PLoS Genet. 2010, 6, e1000978. [CrossRef] [PubMed]

13. Danford, I.D.; Verkuil, L.D.; Choi, D.J.; Collins, D.W.; Gudiseva, H.V.; Uyhazi, K.E.; Lau, M.K.; Kanu, L.N.; Grant, G.R.; Chavali, V.R.; et al. Characterizing the "POAGome": A bioinformatics-driven approach to primary open-angle glaucoma. Prog. Retin. Eye Res. 2017, 58, 89-114. [CrossRef] [PubMed]

14. Burdon, K.P.; Macgregor, S.; Hewitt, A.W.; Sharma, S.; Chidlow, G.; Mills, R.A.; Danoy, P.; Casson, R.; Viswanathan, A.C.; Liu, J.Z.; et al. Genome-wide association study identifies susceptibility loci for open angle glaucoma at TMCO1 and CDKN2B-AS1. Nat. Genet. 2011, 43, 574-578. [CrossRef] [PubMed]

15. Takamoto, M.; Kaburaki, T.; Mabuchi, A.; Araie, M.; Amano, S.; Aihara, M.; Tomidokoro, A.; Iwase, A.; Mabuchi, F.; Kashiwagi, K.; et al. Common variants on chromosome 9p21 are associated with normal tension glaucoma. PLoS ONE 2012, 7, e40107. [CrossRef]

16. Osman, W.; Low, S.K.; Takahashi, A.; Kubo, M.; Nakamura, Y. A genome-wide association study in the Japanese population confirms 9p21 and 14q23 as susceptibility loci for primary open angle glaucoma. Hum. Mol. Genet. 2012, 21, 2836-2842. [CrossRef]

17. Yoshikawa, M.; Nakanishi, H.; Yamashiro, K.; Miyake, M.; Akagi, T.; Gotoh, N.; Ikeda, H.O.; Suda, K.; Yamada, H.; Hasegawa, T.; et al. Association of Glaucoma-Susceptible Genes to Regional Circumpapillary Retinal Nerve Fiber Layer Thickness and Visual Field Defects. Investig. Ophthalmol. Vis. Sci. 2017, 58, 2510-2519. [CrossRef]

18. Holdt, L.M.; Teupser, D. Recent studies of the human chromosome 9p21 locus, which is associated with atherosclerosis in human populations. Arterioscler. Thromb. Vasc. Biol. 2012, 32, 196-206. [CrossRef]

19. Chan, K.; Patel, R.S.; Newcombe, P.; Nelson, C.P.; Qasim, A.; Epstein, S.E.; Burnett, S.; Vaccarino, V.L.; Zafari, A.M.; Shah, S.H.; et al. Association between the chromosome 9p21 locus and angiographic coronary artery disease burden: A collaborative meta-analysis. J. Am. Coll. Cardiol. 2013, 61, 957-970. [CrossRef]

20. Cheng, X.; Shi, L.; Nie, S.; Wang, F.; Li, X.; Xu, C.; Wang, P.; Yang, B.; Li, Q.; Pan, Z.; et al. The same chromosome 9p21.3 locus is associated with type 2 diabetes and coronary artery disease in a Chinese Han population. Diabetes 2011, 60, 680-684. [CrossRef]

21. Olsson, S.; Csajbok, L.Z.; Jood, K.; Nylen, K.; Nellgard, B.; Jern, C. Association between genetic variation on chromosome 9p21 and aneurysmal subarachnoid haemorrhage. J. Neurol. Neurosurg. Psychiatry 2011, 82, 384-388. [CrossRef]

22. Gu, F.; Pfeiffer, R.M.; Bhattacharjee, S.; Han, S.S.; Taylor, P.R.; Berndt, S.; Yang, H.; Sigurdson, A.J.; Toro, J.; Mirabello, L.; et al. Common genetic variants in the 9p21 region and their associations with multiple tumours. Br. J. Cancer 2013, 108, 1378-1386. [CrossRef] 
23. Aarabi, G.; Zeller, T.; Heydecke, G.; Munz, M.; Schafer, A.; Seedorf, U. Roles of the Chr.9p21.3 ANRIL Locus in Regulating Inflammation and Implications for Anti-Inflammatory Drug Target Identification. Front. Cardiovasc. Med. 2018, 5, 47. [CrossRef] [PubMed]

24. Zhao, W.; Smith, J.A.; Mao, G.; Fornage, M.; Peyser, P.A.; Sun, Y.V.; Turner, S.T.; Kardia, S.L. The cis and trans effects of the risk variants of coronary artery disease in the Chr9p21 region. BMC Med. Genom. 2015, 8, 21. [CrossRef] [PubMed]

25. Congrains, A.; Kamide, K.; Katsuya, T.; Yasuda, O.; Oguro, R.; Yamamoto, K.; Ohishi, M.; Rakugi, H. CVD-associated non-coding RNA, ANRIL, modulates expression of atherogenic pathways in VSMC. Biochem. Biophys. Res. Commun. 2012, 419, 612-616. [CrossRef] [PubMed]

26. Qiu, J.J.; Wang, Y.; Liu, Y.L.; Zhang, Y.; Ding, J.X.; Hua, K.Q. The long non-coding RNA ANRIL promotes proliferation and cell cycle progression and inhibits apoptosis and senescence in epithelial ovarian cancer. Oncotarget 2016, 7, 32478-32492. [CrossRef] [PubMed]

27. Congrains, A.; Kamide, K.; Ohishi, M.; Rakugi, H. ANRIL: Molecular mechanisms and implications in human health. Int. J. Mol. Sci. 2013, 14, 1278-1292. [CrossRef]

28. Pasquale, L.R.; Loomis, S.J.; Kang, J.H.; Yaspan, B.L.; Abdrabou, W.; Budenz, D.L.; Chen, T.C.; Delbono, E.; Friedman, D.S.; Gaasterland, D.; et al. CDKN2B-AS1 genotype-glaucoma feature correlations in primary open-angle glaucoma patients from the United States. Am. J. Ophthalmol. 2013, 155, 342-353.e5. [CrossRef]

29. Restrepo, N.A.; Laper, S.M.; Farber-Eger, E.; Crawford, D.C. Local genetic ancestry in CDKN2B-AS1 is associated with primary open-angle glaucoma in an African American cohort extracted from de-identified electronic health records. BMC Med. Genom. 2018, 11, 70. [CrossRef]

30. Liu, Y.; Hauser, M.A.; Akafo, S.K.; Qin, X.; Miura, S.; Gibson, J.R.; Wheeler, J.; Gaasterland, D.E.; Challa, P.; Herndon, L.W.; et al. Investigation of known genetic risk factors for primary open angle glaucoma in two populations of African ancestry. Investig. Ophthalmol. Vis. Sci. 2013, 54, 6248-6254. [CrossRef]

31. Cao, D.; Jiao, X.; Liu, X.; Hennis, A.; Leske, M.C.; Nemesure, B.; Hejtmancik, J.F. CDKN2B polymorphism is associated with primary open-angle glaucoma (POAG) in the Afro-Caribbean population of Barbados, West Indies. PLoS ONE 2012, 7, e39278. [CrossRef]

32. Gudiseva, H.V.; Verma, S.S.; Chavali, V.R.M.; Salowe, R.J.; Lucas, A.; Collins, D.W.; Rathi, S.; He, J.; Lee, R.; Merriam, S.; et al. Genome wide-association study identifies novel loci in the Primary Open-Angle African American Glaucoma Genetics (POAAGG) study. BioRxiv 2020. [CrossRef]

33. Gudiseva, H.V.; Hansen, M.; Gutierrez, L.; Collins, D.W.; He, J.; Verkuil, L.D.; Danford, I.D.; Sagaser, A.; Bowman, A.S.; Salowe, R.; et al. Saliva DNA quality and genotyping efficiency in a predominantly elderly population. BMC Med. Genom. 2016, 9, 17. [CrossRef]

34. Verkuil, L.; Danford, I.; Pistilli, M.; Collins, D.W.; Gudiseva, H.V.; Trachtman, B.T.; He, J.; Rathi, S.; Haider, N.; Ying, G.S.; et al. SNP located in an AluJb repeat downstream of TMCO1, rs4657473, is protective for POAG in African Americans. Br. J. Ophthalmol. 2019, 103, 1530-1536. [CrossRef]

35. Chavali, V.R.M.; Haider, N.; Rathi, S.; Vrathasha, V.; Alapati, T.; He, J.; Gill, K.; Nikonov, R.; Duong, T.T.; McDougald, D.S.; et al. Dual SMAD inhibition and Wnt inhibition enable efficient and reproducible differentiations of induced pluripotent stem cells into retinal ganglion cells. Sci. Rep. 2020, 10, 11828. [CrossRef] [PubMed]

36. Sibin, M.K.; Dhananjaya, I.B.; Narasingarao, K.V.; Harshitha, S.M.; Jeru-Manoj, M.; Chetan, G.K. Two gene polymorphisms (rs4977756 and rs11515) in CDKN2A/B and glioma risk in South Indian population. Meta Gene 2016, 9, 215-218. [CrossRef] [PubMed]

37. Cunnington, M.S.; Santibanez Koref, M.; Mayosi, B.M.; Burn, J.; Keavney, B. Chromosome 9p21 SNPs Associated with Multiple Disease Phenotypes Correlate with ANRIL Expression. PLoS Genet. 2010, 6, e1000899. [CrossRef] [PubMed]

38. Liton, P.B.; Challa, P.; Stinnett, S.; Luna, C.; Epstein, D.L.; Gonzalez, P. Cellular senescence in the glaucomatous outflow pathway. Exp. Gerontol. 2005, 40,745-748. [CrossRef]

39. Zhu, L.; Zhang, Q.; Li, S.; Jiang, S.; Cui, J.; Dang, G. Interference of the long noncoding RNA CDKN2B-AS1 upregulates miR-181a-5p/TGFbetaI axis to restrain the metastasis and promote apoptosis and senescence of cervical cancer cells. Cancer Med. 2019, 8, 1721-1730. [CrossRef]

40. Takai, Y.; Tanito, M.; Ohira, A. Multiplex cytokine analysis of aqueous humor in eyes with primary open-angle glaucoma, exfoliation glaucoma, and cataract. Investig. Ophthalmol. Vis. Sci. 2012, 53, 241-247. [CrossRef] 
41. Wallace, D.M.; Pokrovskaya, O.; O’Brien, C.J. The Function of Matricellular Proteins in the Lamina Cribrosa and Trabecular Meshwork in Glaucoma. J. Ocul. Pharmacol. Ther. 2015, 31, 386-395. [CrossRef]

42. Chen, D.; Zhang, Z.; Mao, C.; Zhou, Y.; Yu, L.; Yin, Y.; Wu, S.; Mou, X.; Zhu, Y. ANRIL inhibits p15(INK4b) through the TGFbeta1 signaling pathway in human esophageal squamous cell carcinoma. Cell. Immunol. 2014, 289, 91-96. [CrossRef] [PubMed]

43. Wiggs, J.L.; Yaspan, B.L.; Hauser, M.A.; Kang, J.H.; Allingham, R.R.; Olson, L.M.; Abdrabou, W.; Fan, B.J.; Wang, D.Y.; Brodeur, W.; et al. Common variants at 9p21 and 8q22 are associated with increased susceptibility to optic nerve degeneration in glaucoma. PLoS Genet. 2012, 8, e1002654. [CrossRef] [PubMed]

44. Wang, C.; Kane, M.A.; Napoli, J.L. Multiple retinol and retinal dehydrogenases catalyze all-trans-retinoic acid biosynthesis in astrocytes. J. Biol. Chem. 2011, 286, 6542-6553. [CrossRef] [PubMed]

45. Kel, A.E.; Gossling, E.; Reuter, I.; Cheremushkin, E.; Kel-Margoulis, O.V.; Wingender, E. MATCH: A tool for searching transcription factor binding sites in DNA sequences. Nucleic Acids Res. 2003, 31, 3576-3579. [CrossRef]

46. Folkersen, L.; Kyriakou, T.; Goel, A.; Peden, J.; Malarstig, A.; Paulsson-Berne, G.; Hamsten, A.; Hugh, W.; Franco-Cereceda, A.; Gabrielsen, A.; et al. Relationship between CAD risk genotype in the chromosome 9p21 locus and gene expression. Identification of eight new ANRIL splice variants. PLoS ONE 2009, 4, e7677. [CrossRef] [PubMed]

47. Burd, C.E.; Jeck, W.R.; Liu, Y.; Sanoff, H.K.; Wang, Z.; Sharpless, N.E. Expression of linear and novel circular forms of an INK4/ARF-associated non-coding RNA correlates with atherosclerosis risk. PLoS Genet. 2010, 6, e1001233. [CrossRef]

48. Broadbent, H.M.; Peden, J.F.; Lorkowski, S.; Goel, A.; Ongen, H.; Green, F.; Clarke, R.; Collins, R.; Franzosi, M.G.; Tognoni, G.; et al. Susceptibility to coronary artery disease and diabetes is encoded by distinct, tightly linked SNPs in the ANRIL locus on chromosome 9p. Hum. Mol. Genet. 2008, 17, 806-814. [CrossRef]

49. Congrains, A.; Kamide, K.; Oguro, R.; Yasuda, O.; Miyata, K.; Yamamoto, E.; Kawai, T.; Kusunoki, H.; Yamamoto, H.; Takeya, Y.; et al. Genetic variants at the 9p21 locus contribute to atherosclerosis through modulation of ANRIL and CDKN2A/B. Atherosclerosis 2012, 220, 449-455. [CrossRef]

50. Kotake, Y.; Nakagawa, T.; Kitagawa, K.; Suzuki, S.; Liu, N.; Kitagawa, M.; Xiong, Y. Long non-coding RNA ANRIL is required for the PRC2 recruitment to and silencing of p15(INK4B) tumor suppressor gene. Oncogene 2011, 30, 1956-1962. [CrossRef]

51. Yap, K.L.; Li, S.; Munoz-Cabello, A.M.; Raguz, S.; Zeng, L.; Mujtaba, S.; Gil, J.; Walsh, M.J.; Zhou, M.M. Molecular interplay of the noncoding RNA ANRIL and methylated histone H3 lysine 27 by polycomb CBX7 in transcriptional silencing of INK4a. Mol. Cell 2010, 38, 662-674. [CrossRef]

52. Puvvula, P.K. LncRNAs Regulatory Networks in Cellular Senescence. Int. J. Mol. Sci. 2019, $20,2615$. [CrossRef] [PubMed]

53. Montes, M.; Lund, A.H. Emerging roles of lncRNAs in senescence. FEBS J. 2016, 283, 2414-2426. [CrossRef] [PubMed]

54. Zhang, Y.; Alexander, P.B.; Wang, X.F. TGF-beta Family Signaling in the Control of Cell Proliferation and Survival. Cold Spring Harb. Perspect. Biol. 2017, 9. [CrossRef] [PubMed]

(C) 2020 by the authors. Licensee MDPI, Basel, Switzerland. This article is an open access article distributed under the terms and conditions of the Creative Commons Attribution (CC BY) license (http://creativecommons.org/licenses/by/4.0/). 